\title{
PENGARUH IKLAN, PESTER POWER DAN PENEMPATAN PRODUK TERHADAP KEPUTUSAN PEMBELIAN ORANG TUA PADA KINDER JOY DI GIANT EKSPRESS MATARAM
}

\author{
Oleh \\ Asri Oktiani $^{1)}$ \& Nurul Marlianti ${ }^{2)}$ \\ 1,2Sekolah Tinggi Ilmu Ekonomi 45 Mataram \\ Email: ${ }^{1}$ asrioktian84@gmail.com \& 2 liamarlianti87@gmail.com
}

\begin{abstract}
Abstrak
Di era Modern pemasar mulai melirik pasar anak-anak sebagai sasaran pemasaran produknya, anakanak dianggap sebagai pemberi pemberi pengaruh pada proses keputusan membeli orangtua. Penelitian ini dilakukan untuk mengetahui pengaruh pester power, penempatan produk dan pengaruh iklan terhadap keputusan orang tua membeli kinderjoy untuk anaknya. Jenis penelitian yang dilakukan adalah penelitian kuantitatif, tujuan dari penelitian ini adalah untuk mengetahui pengaruh variabel independen terhadap variabel dependent. Sebanyak 48 responden yang melakukan pembelian di Giant express Mataram selama bulan agustus 2020 dijasikan responden dalam penelitian. Hasil penelitian menunjukkan bahwa variabel Pester Power (X1), Penempatan Produk (X2) dan juga pengaruh iklan ( X3) berpengaruh secara parsial dan simultan terhadap keputusan orang tua membelikan kinder joy untuk anaknya hal ini dibuktikan dengan melihat nilai sig. Kurang dari 0.05, sedangkan fariabel pester power (X1) menjadi variabel yang dominan dengan nilai beta tertinggi yakni 0,784 sehingga ketiga hipotesis yang diajukan diterima.
\end{abstract}

Kata Kunci: Pester Power, Pengaruh Iklan, Penempatan Produk \& Keputusna Konsumen

\section{PENDAHULUAN}

Persaingan bisnis saat ini sangat kompetitif, pemasar berlomba-lomba untuk membuat produk yang dihasilkan mendapat tempat di konsumen. Produsen saat ini tidak hanya fokus pada pasar orang dewasa melainkan juga membidik pasar anak- anak dan menganggap segmen anak-ana merupakan pasar potensial untuk mendapat keuntungan dan positioning produk yang kuat. Anak- anak menjadi sasaran pemasar karena mereka memiliki pengaruh besar mempengaruhi orang tua melakukan pembelian secara langsung atau tidak langsung.

Di zaman modern seperti saat ini anakanak mampu mengadaptasi informasi yang didapat dari media elektronik sehingga anak mampu mengubah dan mendorong orang tua dalam memutuskan untuk membeli produk yang mereka inginkan. Kemampuan anak untuk mempengaruhi orang tua untuk melakukan pembelian untuknya merupakan fenomena pester power. Pester power dapat didefinisikan sebagai meminta secara berulang untuk produk atau layanan yang spesifik (Quinn, 2015), yang menunjukkan perjuangan seorang anak untuk memodifikasi pikiran orang tua dengan cara meminta berulang-ulang dan cenderung dengan cara Sedikit melawan. Pemasaran berbasis pester power mentargetkan anak-anak yang tak mampu membeli produk untuk diri mereka sendiri, dan mempercayai orang tua untuk membelinya. Beberapa produk yang memungkinkan untuk menggunakan strategi pester power adalah produk yang berhubungan dengan anak-anak seperti mainan dan makanan ringan, manisan dan coklat. Selain itu penempatan produk di tempat yang mudah dilihat oleh anak- anak akan berpengaruh ke keinginan untuk membei dan akan mempengaruhi orang tuanya untuk melakukan pembelian.berbagai macam strategi dilakukakn untuk menarik minat anak- anak seperti periklanan yang menarik sampai kemasan yang menarik bagi anak-anak.

Studi empiris yang dilakukan oleh Kevin Gunawan ( 2019) melaksanakan penelitian pengaruh persuasive dan emotional pester terhadap keputusan pembelian, hasil dari penelitian tersebut bahwa emostional pester 
pengaruhnya lebih besar daripada persuasive pester terhadap keputusan konsumen. Selain itu penempatan produk di kasir di dalam toko retail mempengaruhi konsumen untuk memutuskan membeli suatu produk dengan implikasi meningkatkan penjualan toko bahkan perusahaan, peryataan ini didukung oleh hasil penelitian dari Dian Tauriana dan Ika Fietrin ( 2011).

"Kinder Joy" merupakan salah satu snack cokelat favorit yang digemari anak-anak karena kemasan yang unik dengan bentuk telur, memiliki rasa yang enak dan juga terdapat hadiah didalamnya berupa mainan, stiker, kartu, dan banyak jenis hadiah lain didalamnya. Sehingga tidak hanya anak-anak yang menyukai peroduk ini namun orang dewasa menyukai kinder joy juga (idntimes.com).

Di kota mataram khususnya di kecamatan Mataram kinder joy menjadi favorit anak-anak, ditandai dengan keberadaan produk yang gampang dijumpai di beberapa minimarket di wilayah kecamatan Mataram, untuk lebih menarik minat anak-anak sering terlihat pihak pengelola minimarket meletakkan produk dekat dengan kasir sehingga mudah terlihat oleh anak-anak dengan tujuan mereka akan tertarik dan meminta orang tua untuk membeli.

Berdasarkan hal yang terjadi maka pengaruh dari pester power dan penempatan produk sangatlah penting terhadap keputusan orang tua membeli kinderjoy dan kami akan mengangkat tema "Pengaruh Iklan, Pester Power Dan Penempatan Produk Terhadap Keputusan Pembelian Orang Tua Pada Kinder Joy Di Giant Ekspress Mataram ".

\section{LANDASAN TEORI}

Penelitian yang dilakukan oleh Florentina K. Tehubijuluw dan Desy Permata Sari tahun 2017 dengan judul "Pengaruh Bauran Pemasaran, Pester Power, Dan Heritage Terhadap Keputusan Pembelian Biskuit Merek Roma Malkist" penelitian bertujuan untuk mengetaui pengaruh variabel marketing mix, pester power dan heritage terhadap keputusan konsumen di wilayah tangerang. Penelitian yang dilakukan merupakan penelitian kuantitatif dengan 155 orang responden yang diambil dengan metode non-probability sampling. Hasil dari penelitian adalah bahwa variabel produk, harga dan heritage merupakan variabel yang memliki pengaruh signifikan terhadap keputusan pembelian konsumen , sedangkan variabel promosi, distribusi dan pester power merupakan variabel yang tidak berpengaruh secara signifikan terhadap keputusan pembelian . variabel produk dan heritage merupakan variabel yang domian pengaruhnya terhadap keputusan konsumen memiliki pengaruhnya terhadap keputusan konsumen membeli produk roma malkist.

Penelitian kedua oleh Kevin Gunawan tahun 2019 denga judul "pengaruh pester power terhadap keputusan pembelian oleh orang tua pada produk mainan di malang" penelitian ini menganalisis pengaruh signifikansi pester power terhadap keputusan pembelian oleh orang tua pada produk mainan di Malang. Pendekatan penelitian yang digunakan merupakan penelitian kuantitatif, penelitian ini untuk mengetahui dan menguji hipotesis tentang ada tidaknya pengaruh persuasive pester dan emotional pester terhadap keputusan pembelian. Populasi dalam penelitian ini adalah orang tua di kota Malang yang memiliki anak di rentang usia 2-5 dan 5-11 di sekolah TK dan SD. Hasil penelitian menunjukkan tidak adanya adanya pengaruh signifikan antara persuasive pester terhadap keputusan pembelian. Oleh karena itu, hipotesis pertama yang menyatakan bahwa: Persuasive Pester berpengaruh signifikan terhadap keputusan pembelian oleh orang tua pada produk mainan di kota Malang, ditolak. Selanjutnya dari hasil penelitian diketahui bahwa pengaruh signifikan emotional pester terhadap keputusan pembelian oleh orang tua. Oleh karena itu, hipotesis kedua yang menyatakan bahwa: Emotional Pester berpengaruh signifikan terhadap keputusan pembelian oleh orang tua pada produk mainan di kota Malang, diterima.

Penelitian ketiga merupakan penelitian yang dilakukan oleh Dian Tauriana dan Ika Fietrin tahun 2012 dengan judul "Pengaruh Penempatan Produk Di Kasir Dan Sales Person Terhadap Impulse Buying". Penempatan produk di kasir dan sales person memiliki dampak penting bagi impulse buying dalam ritail yang akan meningkatkan penjualan perusahaan. Penelitian bertujuan untuk mengetahui pengaruh 
penempatan produk di kasir dan sales person terhadap impulse buying GIANT Hipermarket Plaza Semanggi. Penelitian yang dilakukan merupakan penelitian asosiatif, Teknik pengumpulan data dilakukan dengan menyebarkan kuesioner pada konsumen yang belanja di GIANT Hipermarket Plaza Semanggi dan melakukan wawancara pada pihak manajemen di Toko tempat penelitian dilaksanakan. Teknik analisis data yang digunakan adalah uji validitas dan reliabilitas, uji normalitas, uji regresi sederhana dan uji regresi beganda dengan bantuan software SPSS versi 16.0. Hasil penelitian ini menunjukkan bahwa variabel penempatan produk di kasir dan sales person berpengaruh secara simultan dan signifikan terhadap impulse buying.

Iklan.

Iklan adalah segala bentuk presentasinonpribadi dan promosi gagasan, barang, ataujasa oleh sponsor tertentu yang harus dibayar(Kotler dan Keller, 2007), sedangkan menurutTjiptono (2001) iklan dapat dimanfaatkan secara efektif untuk membangun citra jangka panjang produk maupun perusahaan dan juga dapatmemicu pembelian segera. Iklan juga digunakan untuk mengarahkan dan membentuk pilihan terhadap suatu merek. Iklan juga merupakan ajang kompetisi bagi setiap produk untuk mengalahkan produk saingannya, dengan cara iklan yang menyerang produk pesaing dan menampilkan produk pesaing secara tidak langsung menunjukkan kekurangan dari produk yang pesaing tawarkan. Disamping itu, iklan menjadi salah satu hiburan bagi konsumen secara atraktif terkadang ditambahkan dengan menampilkan karakter kartoon atau animasi yang lucu dan menjadi favorit anak-anak jika sasaran produknya merupakan anak-anak.

Ada lima keputusan yang harus diambilberdasarkan $5 \mathrm{M}$ yang dianut dalam duniaperiklanan ( Kotler dan Keller, 2007) :

1.Mission (Misi)

a)Memberi informasi

b)Mengajak

c)Mengingatkan

d)Mendorong terjadinya keputusan untukmembeli suatu produk

2.Message (Pesan)
Pesan yang disampaikan dalam iklan harusnya mampu menyampaikan kelebihan yang ada pada produk melalui kalimat, kata-kata maupun gambar.

Iklan juga merupakan sebuah alat yang komunikasi yang menceritakan pada konsumen mengenai detail dari produk tersebut.

3.Media

Produsen hendanya memilih media yang memiliki kemampuan menjangkau pasar sasaran yang dianggap sangat efektif tanpa melupakan sisi biaya yang harus di keluarkan, Media dianggap Alat terbaik menyalurkan iklan. 4.Money (Pembiayaan)

Perkiraan biaya untuk iklan berdasarkan harga yang ditetapkan untuk setiap fungsi, jangkauan pemasaran, frekuensi dan dampak yang diinginkan. Anggaran ini harus juga memperhitungkan tagihan yang harus dibayar oleh oleh pihak perusahaan terhadap biaya untuk setiap kali iklan dibuat dan biaya-biaya lain. Namun iklan terbaik tidak dilihat dari biaya yang sangat besar, tetapi isidan pesan dari iklan mampu menjelaskan kegunaan produk dan kelebihan yang dimiliki kepada pasar sasaran yang diharapkan membeli produk.

5.Measurement ( Tolok Ukur )

Maksud dari ukuran dalam iklan adalah standar yang didapat setelah iklan tersebut dikampanyekan. Berhasilkah iklan tersebutatau malah memperburuk image brand produk tersebut. Hal tersebut nantinya akandilihat dari kesuksesan penjualan produkdan tanggapan masyarakat mengenai produk berkaitan dengan iklan yang telah ditayangkan.

Penempatan produk

Penempatan produk/ display bisa diartikan adalah penempatan barang dengan melihat komponen jenis barang dan kegunaannya, penataan yang teratur dan memberikan kesan menarik akan membuat konsumen melihat dan mempengaruhi pikiran konsumen untuk membeli ( peter\& Olson: 2000). Tata letak dan susunan produk yang ada dalam toko akan dipajang ikut berpengaruh terhadap keputusan konsumen( Hawkins, 2004). Kejelasan letak dari produk akan berimbas pada jelasnya posisi produk dan waktu yang digunakan untuk konsumen dalam berbelanja akan menjadi lebih singkat karena 
produk mudah dicari konsumen ( kusumowidagdo, 2005). Aturan dalam mengatur dan memposisikan produk mengikuti pola pikir konsumen. Pola pikir konsumen dalam hal ini mengacu kepada cara konsumen berfikir, dan minat konsumenyang diharapkan akan berpengaruh terhadap perilaku pembelian saat berada dalam toko. Contoh kousumen yang biasa berbelanja untuk keperluan bulanan akan otomatis menuju tempat produk diletakkan karena mereka melakukan pembeliannya hampir setiap bulannya. Produsen melihat hal ini nemempatkan letak produk sebagi salah satu faktor penentu konsumen memutuskan untuk membeli.

Effendy (2003) pengertian Display menurut bahasa dan katanya yang berasal dari bahasa latin yang terdiri dari dua kata antara lain : dis yang berarti terpisah dan plicare yang diartikan membuka lipatan untuk melihat. Sehingga display diartikan melihat posisi produk dengan jelas dari tempat yang tersusun atau tempat produk diletakkan.

Adanya penempatan produk dalam kegiatan promosi sangatlah penting. Menurut Winardi ( 1992) menyebutkan bahwa display dikategorikan dalam " trade promotion devices" yang berarti salah satu desain dalam promosi penjualan yang didesain khusus untuk memancing penjual menunjukkan dan secara cepat dalam memasarkan produk kepada Wholsaler, pengecer dan juga langsung kepada konsumen. Penempatan produk ( display Produk) sangat memiliki peranan yang penting untuk membuat konsumen tertarik walaupun pada awalnya hanyamelihat produk, imbas yang diharapkan dari penempatan produk yaitu terjadi pembelian yang berimbas pada meningkatnya jumlah transaksi dan keuntungan bag perusahaan pada periode mendatang.

Adapun jenis display yaitu Display terbuka, Window Display, Assortmen display, Ensemble display, Theme setting display, Display gaya hidup, Display terkoordinasi terkoordinasi, Display yang didominasi kategori produk, Power aisles, Nama atau konsensi, Case display, Cut case, Display teknik tertentu, Point of purchase, Exterior display dan tampilan New Product Introduction(Akhter, 2012).

Pester power
Pester power diartikan dengan didefinisikan sebagai meminta secara berulang terhadap produk atau layanan yang khusus (Quinn,2002), digambarkan dengan usaha seseorang anak buat mensugesti daya beli orang tua secara berulang-ulang dan biasanya dengan cara konfrontatif untuk mendapatkan yang anakanak inginkan (Nicholls dan Cullen, 2004). Anakanak memiliki kekuatan untuk mempengaruhi keluarga mereka saat berada pada rentang usia 5 sampai 11 tahun (Bennett, 1991), dan pengaruhnya akan menjadi lebih kuat saat mereka bertumbuh (Mowen dan Minor, 2000).

Peran influencer yang ditunjukkan oleh anak-anak selama keputusan pembelian dalam keluarga memberikan efek tersendiri terhadap orang tua mereka, karena meskipun masih berusia 2 tahun, anak sudah terlibat aktif dan mulai mempengaruhi keputusan pembelian. Kekuatan anak-anak, dengan mengomel berulang-ulang, mempengaruhi orang tua untuk membelikan barang-barang yang mereka inginkan disebut sebagai pester power (Akhter, 2012).

Pemasaran berbasis pester power mentargetkan anak-anak yang tak mampu membeli produk untuk diri mereka sendiri, dan mempercayai orang tua mereka untuk membelinya. Sebagai contoh, meskipun anakanak di India tidak memiliki banyak daya beli dibandingkan dengan rekan-rekan di negara bagian barat namun tetap memainkan peran yang sangat penting dalam mempengaruhi keputusan orang tua. Bagi keluarga orang India, anak-anak selalu menjadi pusat alam semesta dan mereka benar-benar dapat menekan orang tua mereka untuk hal tertentu. Hal ini dibuktikan dengan pengaruh daya beli produk yang berhubungan dengan anak-anak seperti mainan, pakaian dan camilan yang identic dengan anak-anak lebih memiliki rasio penjualan yang tinggi (Kaur dan Singh, 2016)

Anak- anak umumnya mereka menginginkan barang yang ada dan tampak didepan atau sekitar mereka. Anak-anak cenderng menggunakan strategi persuasive pester dan emosional pester untuk mendapatkan apa yag diinginkan. Terkadang orang tua akan terpengaruh dengan strategi pester power yang anak-anak gunakan. ( gunawan kevin, 2019) 
Keputusan pembelian

Dalam membeli suatu barang atau jasa, seorang konsumen akan melalui suatu tahapan keputusan pembelian. Menurut Ma'Ruf (2006), membagi tahapan keputusan pembelian antara lain:

1. Proses keputusan panjang (extended decision making) untuk barang yang tahan lama (durable) seperti: tanah, perumahan, kendaraan dan lainnya. menurut Berman dan Evans, dalam Ma'ruf (2006) adalah Yang membagi tahapan tersebut menjadi Stimulus - Kebutuhan - Mencari info - evaluasi Transaksi - Perilaku pasca pembelian. Stimulus disini diartikan dengan kondisi yang memicu timbulnya kebutuhan yang berasal dari dalam diri konsumen.

2. Proses keputusan terbatas (Limited decision making), pada dasarnya tahapannya sama dengan proses keputusan yang panjang namun denan waktu yang lebih cepat dan bisa melewatkan beberapa tahan. Proses terbatas berlau untuk produk seperti baju, perlengkapan sekolah anak dan paket wisata.

3.Proses pembeliam rutin, proses pembelian ini terjadi berulang dan membuat keputusna pembelian yang terjadi begitu saja. Pembelian terjadi jika ada kebutuhan yang muncul.

Keputusan pembelian merupakan tahapan akhir dari kosumen setelah melakukan beberapa tahapan salah satunya adalah memilih produk. Jika konsumen telah menentukan pilihan terhadap alternatif yang ada maka mereka akan melakukan pembelian. Menurut kotler ( 2005) menentukan empat perilaku konsumen pada saat melakukan pembelian, antara lain:

1.Perilaku Pembelian yang Rumit Perilaku pembelian yang rumit yang terdiri dari tiga tahapan : pertama pembeli akan menetapkan keyakinan terhadap produk tertentu. Kedua, konsumen akan menentukan sikap terhadap suatu produk. Ketiga konsumen akan memutuskan dan menentukan pilihan pembelian yang akan dia lakukan.

2.Perilaku Pembeli Pengurang Ketidaknyamanan, konsumen sering dihadapkan pada sebuah pilihan pembelian akan tetapi akan sedikit perbedaan pada pilihan merek. Konsidi ini membuat konsumen tidak akan melakukan pembelian yang memiliki resiko tinggi. Pembelian yang akan dilakukan dengan membandingkan perbedaan mutu, dan harga.

3.Perilaku konsumen dengan teterlinatan rendah melompati keyakinan, sikap dan perilaku dalam pembeliannya. Dalam tahapan ini konsumen tidak akan melakukan perbandingan merek harga dan juga kualitas produk melainkan mereka hanya akan melihat informasi produk dari iklan dan promosi yang dilakukan suatu merek tertentu.

Perilaku pembelian

4.Perilaku pembelian yang mencari variasi, ditunjukkan dengan situasi konsumen yang membandingkan merek satu dengan lainnya. Perpindahan merek in mereka lakukan karena mereka mencari perubahan suasana baru dan bukan karena perasaan tidak puas terhadap produk yang ada.

\section{Gambar 1. Keranga konseptual penelitian}

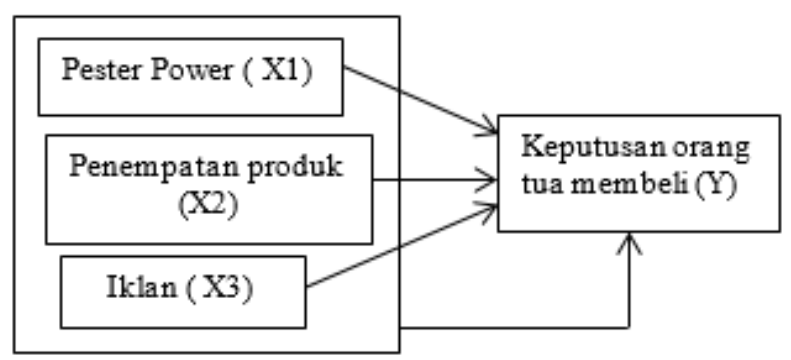

Dari landasan teori dan penelitian terdahulu maka dapat dirumuskan hipotesis penelitian sebagai berikut:

1. Pester power, Penempatan produk di kasir dan iklan berpengaruh Parsial terhadap keputusan orang tua membeli kinderjoy untuk anaknya

2. Pester power, Penempatan produk di kasir dan iklan berpengaruh Parsial terhadap keputusan orang tua membeli kinderjoy untuk anaknya

3. Pester power merupakan merupakan variabel yang dominan berpengaruh terhadap keputusan orang tua membeli kinder joy untuk anaknya.

\section{METODE PENELITIAN}

Jenis penelitian

Jenis penelitian ini adalah penelitian kuantitatif, penelitian kuantitatif adalah penelitian ilmiah yang sistematis terhadap bagian-bagian dan fenomena serta hubungan-hubungannya ( Sugiyono,2012).

Populasi dan sampel 
Penelitian ini menggunakan metode nonprobability sampling, yaitu teknik pengambilan sampel yang tidak memberi Peluang atau kesempatan yang sama bagi setiap unsur atau anggota populasi untuk dipilih menjadi sampel serta menggunakan teknik judgemental sampling untuk mengumpulkan informasi dari para Anggota populasi yang dipilih berdasarkan kriteria yang telah dirumuskan terlebih dahulu oleh peneliti (Sugiarto et.al, 2015). Kriteria pengambilan sampel adalah orang tua yang melakukan pembelian kinder joy dengan anak rentang usia 5-8 tahun di Indomaret Sriwijaya sebanyak 48 orang dalam rentang waktu 1 bulan yang kemudian ditentukan sebagai responden dalam penelitian ini.

Metode pengumpulan data

Teknik pengumpulan data dilakukan dengan memberikan kuesioner yang diberikan secara langsung kepada responden penelitian, yakni orangtua yang melakukan pembelian kinder joy untuk anak mereka yang berusia 5 sampai 8 tahun . Kuesioner yang diberikan berisi beberapa pernyataan terkait variabel-variabel penelitian ini kepada responden penelitian dengan skala likert 1 sampai 5, adapun variabel dari penelitian ini adalah pester power ( X1 ) dan Penempatan produk di kasir ( X2) dan iklan ( x3) sebagai variabel Bebas dan keputusan konsumen (Y) sebagai variabel terikat.

Metode analisis data

Agar instrumen yang dipakai dalam penelitian ini dapat berfungsisebagaimana yang diharapkan, maka instrumen tersebut perlu diuji validitas dan reliabilitasnya. Kriteria satu variabel dikatakan valid bisa dilihat dari nilai KMO harus $>0,500$ dan nilai signifikan barllet's tes < 0,05 ( Bilsom Simamora,2003). Uji reliabilitas digunakan untuk mengetahui apakah indikator dari variabel dikatakan handal atau reliabel. Dikatakan baik atau handal jika memiliki nilai cronbach's alpha $>0,60$.

Dalam analisi regresi linier berganda, selain mengukur kekuatan hubungan antara dua variabel atau lebih, juga menunjukan arah hubungan antara variabel dependent dengan variabel independent yang di tampilkan dengan persamaan sebagai berikut:

$$
\mathrm{Y}=\alpha+\mathrm{b} 1 \mathrm{X} 1+\mathrm{b} 2 \mathrm{X} 2+\mathrm{b} 3 \mathrm{X} 3+\mathrm{e}
$$

Uji t digunakan untuk melihat tingkat signifikansi variabel independen mempengaruhi variabel dependen secara individu atau sendiri-sendiri dengan melihat nilai sig. $<0.05$ dan nilai Beta yang dihasilkan. Uji f digunakan untuk melihat hubungan variabel bebas terhadap variabel terikat dengan membandingkan nilai $\mathrm{f}$ hitung dan $\mathrm{f}$ tabel. Jika $\mathrm{f}$ hitung $>$ dari $\mathrm{f}$ tabel artinya terdapat pengaruh secara simultan dari variabel bebas terhadap variabel terikat.

\section{HASIL DAN PEMBAHASAN}

Dari hasil penelitian yang telah dilakukan menunjukkan bahwa seluruh item pertanyaan dari kuesioner yang dibagikan mempunyai nilai KMO $>0,500$ dan nilai signifikan barllet's test dibawah 0,05 sehingga semua indikator dari variabel dalam penelitian dinyatakan valid sebagai alat ukur. Sedangkan analisis reliability seluruh variabel bisa dikatakan reliabel atau handal karena nilai alpha lebih $>0.60$, jadi bisa disimpulkan bahwa kuesioner dalam penelitian ini dapat dikatakan layak sebagai instrumen untuk mengukur dan meneliti variabel. Dari analisis regresi linier berganda diperoleh persamaan sebagai berikut:

\section{$Y=1,651+0,378 \times 1+0,870 \times 2+0,158 \times 3$}

Untuk lebih jelasnya Koefisien Regresi dijabarkan seperti dibawah ini:

Konstanta sebesar1,651 menyatakan bahwa jika tidak ada kebijakan variabel bebas Pester Power ( X1) , penempatan produk di kasir ( X2) dan pengaruh iklan ( X3) dan maka keptusan orang tua membelikan kinderjoy untuk anaknya sebanyak $16,51 \%$

Nilai koefisien untuk variebel Pester Power (X1) sebesar 0,378 dengan sig $\quad(0.000$ $<0.05)$ dengan nilai sig. 0,000. Hal ini berarti bahwa bila nilai variabel bebas tetap nilainya dan nilai $\mathrm{B}$ adalah 0,378 maka jika variabel Pester Power ( X1) meningkat satu satuan maka nilai Y meningkat sebanyak 0,378 dengan asumsi variabel bebas lainnya konstan.

Nilai koefisien untuk variabel penempatan produk di kasir ( X2) sebesar 0,870 dengan sig ( $0.000<0.05)$ dengan nilai Sig. 0,000. Hal ini berarti bahwa bila nilai variabel bebas tetap nilainya dan nilai $\mathrm{B}$ adalah 0,870 maka jika variabel penempatan produk di kasir ( X2) 
meningkat satu satuan maka nilai $\mathrm{Y}$ meningkat sebanyak 0,870 dengan asumsi variabel bebas lainnya konstan.

Nilai koefisien untuk variebel pengaruh iklan ( X3) sebesar 0,158 dengan sig $(0.000<$ $0.05)$ dengan nilai Sig. 0,036 . Hal ini berarti bahwa bila nilai variabel bebas tetap nilainya dan nilai $B$ adalah 0,158 maka jika variabel pengaruh iklan ( X3) meningkat satu satuan maka nilai Y meningkat sebanyak 0,158 dengan asumsi variabel bebas lainnya konstan.

Dari hasil Jika dilihat dari nilai beta dari masing-masing variabel bebas yakni pada variabel Pester Power ( X1) nilai beta sebesar 0.734 , variabel penempatan produk di kasir (X2) sebesar 0,695 dan Pengaruh iklan ( X3) sebesar 0.127 . Hal ini bisa diasrtikan bahwa variabel dengan nilai beta terbesar merupakan variabel yang paling berpengaruh ( dominan ) berpengaruh terhadap keputusan konsumen. Bisa diartikan dengan melihat nilai beta bahwa semua variabel bebas dalam penelitian ini yakni variabel Pester Power ( X1), Penempatan Produk di kasir ( X2) dan Pengaruh Iklan ( X3) masing -masing berpengaruh ( parsial ) terhadap keputusan konsumen, artinya hipotesis pertama ang diajukan Terbukti / diterima.

Hasil uji $\mathrm{F}$ pada penelitian ini memiliki nilai koefisien sebesar 57,998 dengan nilai signifikansi sebesar $0,000<0,05$. Hasil ini memiliki arti bahwa variabel bebas secara simultan mempunyai pengaruh secara positif dan signifikan terhadap minat nasabah. Jadi bisa disimpulkan bahwa hipotesis yang diajukan diterima/ terbukti.

Dari besarnya besarnya koefisien determinasi $\left(\mathrm{R}^{2}\right)$ sebesar 0,854 . Hasil tersebut menunjukkan bahwa 85,4 \% variabel dependen (Keputusan Konsumen) dapat dijelaskan oleh ketiga variabel independen ( pester power, penempatan produk di kasir dan pengaruh iklan) Sedangkan sisanya $30,8 \% \quad(100 \%-69,2 \%)$ dijelaskan oleh variabel lain yang tidak diteliti dalam penelitian ini.

\section{PENUTUP}

\section{Kesimpulan}

1. Berdasarkan analisis data yang telah dilakukukan secara parsial variabel bebas yang terdiri dari Pester Power ( X1), Penempatan Produk ( X2) dan juga pengaruh iklan ( X3) berpengaruh secara parsial terhadap keputusan orang tua membelikan kinder joy untuk anaknya hal ini dibuktikan dengan melihat nilai sig. Kurang dari 0.05

2. Jika melihat dari nilai beta dari masing-masing variabel bebas yakni pada variabel Pester Power (X1) nilai beta sebesar 0.734 , variabel Penempatan Produk ( X2) sebesar 0,695 dan variabel pengaruh iklan ( X3) sebesar 0.127. hal ini bisa diartikan bahwa variabel dengan nilai beta terbesar merupakan variabel kemudahan yang paling berpengaruh ( dominan ) berpengaruh terhadap keputusan konsumen sebesar 0,743, maka hipotesis ketiga yang menyebutkan bahwa variabel Pester Power merupakan variabel yang dominan berpengaruh terhadap keputusan orang tua membeli kinder joy diterima

3. Berdasarkan uji f diketahui bahwa hasil uji $F$ pada penelitian ini memiliki nilai koefisien sebesar 57,998 dengan nilai signifikansi sebesar $0,000<0,05$. Hasil ini memiliki arti bahwa variabel bebas secara simultan mempunyai pengaruh secara positif dan signifikan terhadap minat nasabah. Jadi bisa disimpulkan bahwa hipotesis yang diajukan diterima

4. Jika dilihat besarnya nilai R2 (R Square) sebesar 0,854. Hasil tersebut menunjukkan bahwa 85,4 \% variabel dependen (Keputusan Konsumen) dapat dijelaskan oleh ketiga variabel independen (( pester power, penempatan produk di kasir dan pengaruh iklan) Sedangkan sisanya $30,8 \% \quad(100 \%$ $69,2 \%$ ) dijelaskan oleh variabel lain yang tidak diteliti dalam penelitian ini.

\section{Saran}

Diharapkan penelitian berikutnya menambahkan variabel yang kemungkinan berpengaruh terhadap minat anak membeli kinder joy dan implikasinya ke orang tua. Penelitin selanjutnya harus memperluas cakupan responden tidak hanya terpaku pada pelanggan yang 
membeli di Giant express saja akan tetapi juga orang tuan yang melakukan pembelian kinderjoy di tempat lainnya juga sebenarnya berpeluang sebagai responden.

\section{DAFTAR PUSTAKA}

[1] Abbassi, A., dan Singh, R. N. (2006). "Assertiveness in Marital Relationships Among Asian Indians in the United States." Journal of the Family. 14, (4), 392-399.

[2] Akhter, N. (2010). Self Management Among Patients With Hypertension in Bangladesh. Ejournal Tersedia secara online di http://kb.psu.ac.th diakses pada 2 Juni 2016

[3] Effendi, Muh. Arief. 2009. The Power Of Corporate Governance: Teori dan Implementasi. Jakarta: Salemba Empat.

[4] Gunawan, kevin ( 2019), Pengaruh Pester Power Terhadap Keputusan Pembelian Oleh Orang Tua Pada Produk Mainan Di Malang. Skrisi Universitas Machung. 2019

[5] Hall. Kotler \& Keller (2012). Marketing Management (14th Ed). Boston: Pearson Education.

[6] Hawkins, Best, Coney, 2004, Consumer Behavior, Building Marketing Strategy International Edition, Mc Graw Hill Companies, Inc

[7] J.Paul Peter \& jerry c. Olson (2000). Consumer Behavior Perilaku Konsumen 2nd. ed. 4 Jakarta: .Penerbit Erlangga

[8] Kotler \& Armstrong (2012). Principles of Marketing. Boston: Pearson Prentice

[9] Kusumowidagdo, Astrid. 2005. Peran Penting Perancangan Interior Pada Store Based Retail. Dimensi Interior. 1 Juni 2005 (17.30).

[10] Quinn (2002). Managing Change. Journal of Leadership and Organizational Studies. 10 (4), pp.112-123.

[11] Sugiyono. ( 2012). Memahami penelitian kualitatif. Bandung. Alfabeta

[12]Tauriana, Dian \& Fietrin,Ika ( 2011). Pengaruh Penempatan Produk Di Kasir Dan Sales Person Terhadap Impulse Buying. Journal The WINNERS, Vol. 12 No. 1, Maret 2011: 61-70

[13] Tehubijuluw, Florentina K. \& Desy Permata Sari ( 2017). Pengaruh bauran pemasaran, pester power, dan heritage terhadap keputusan pembelian biskuit merek roma malkist. Kompetensi - jurnal manajemen bisnis, vol. 12, no. 1, januari - juni 2017

[14] Tjiptono, F (2008). Pemasaran Strategik. Yogyakarta: Andi.

[15] Tjiptono. 2001. Manajemen Pemasaran dan Analisa Perilaku Konsumen, Yogyakarta: BPFE

[16]Winardi. 2016.Kepemimpinan dalam Manajemen. Jakarta: PT. Rineka Cipta. 